\title{
Adapting Marketing Strategies: A Linguistic Analysis of Wine Advertising in Spain, 1970-2010
}

\begin{abstract}
The Spanish wine sector has undergone a series of changes in the last decades, particularly due to the decreasing domestic demand and the growing international competence. Consequently, Spanish wineries have had to adapt to this new situation by adopting new marketing policies. The aim of this study is to explore to what extent these new policies have been applied by means of the linguistic analysis and comparison of different types of advertisement in specialized printed media, focusing on the specific frequency of the most used word families in adverts from the 70s to present day. A corpus of 640 adverts has been compiled. We have particularly paid attention to the words that have been used in those messages. Results reveal that the Spanish wineries started their adaptive process during the 90s. They evolved from simple no picture messages related to the production system to more elaborated and pictured ones with the introduction of new visual support and terms related to tradition, exclusiveness and quality.
\end{abstract}

Keywords: Wine Industry; Marketing Strategies; Advertising; Word frequency

Corresponding author: e-mail: Gema.Alcaraz@uclm.es

Received 13 Sept 2018 - Accepted 17 Nov 2018

This is an Open Access article distributed under the terms of the Creative Commons Attribution-Non-Commercial-No Derivatives License (http://creativecommons.org/licenses/by-nc-nd/4.0/), which permits non-comercial re-use and distribution, provided the original work is properly cited, and is not altered or transformed in any way. 


\section{Introduction}

The Spanish wine sector has undergone a series of important changes. The decreasing demand, the new eating habits and the growing international competence due to the emerging competitors have pushed the Spanish sector to adapt to this new situation. In order to carry out this initiative the Spanish wineries have introduced new technology, have promoted the professionalization of their managers, have adopted marketing policies and have carried out the product diversification.

The aim of this study is to know to what extent this new marketing policy has been applied by Spanish wineries. We analyze different types of advertising, focusing on the specific frequency of the most used word families in adverts from the 70s to present day. A corpus of 640 adverts has been compiled. Adverts have been taken from specialized wine magazines. They have been linguistically analyzed both from a quantitative and a qualitative perspective. We have paid particular attention to the words that have been used in those messages. Accordingly, we have explored the trade image offered by the wine sector and its effect on demand.

The paper is organized as follows: after the introduction, the second chapter delves into the analysis of new trends in the international and domestic wine consumption, through a literature review. Besides, the company structure of the Spanish wine sector and new marketing strategies are described. In the third chapter sources and methodology are described. Finally, results are discussed to finish with some conclusions. 


\section{General approach and literature review}

\subsection{Evolution and change of wine demands in the Mediterranean Europe}

In global terms, the wine demand has experienced a constant decline during the last four decades, falling from 280 million hectolitres between 1971-1975, to 226 in 2000, meaning 20\% less. Despite these figures, in $2011^{1}$ wine consumption increased up to 244 million hectolitres. Figure 1, shows this evolution organized in geographical areas. We can observe that the Mediterranean Europe - which is the main consumption area $^{2}$ (Pinilla and Serrano 2008; Unwin 1991) - has undergone a decrease in the last years.

Figure 1. Wine consumption in the main regions (litres per capita), 1970-2010

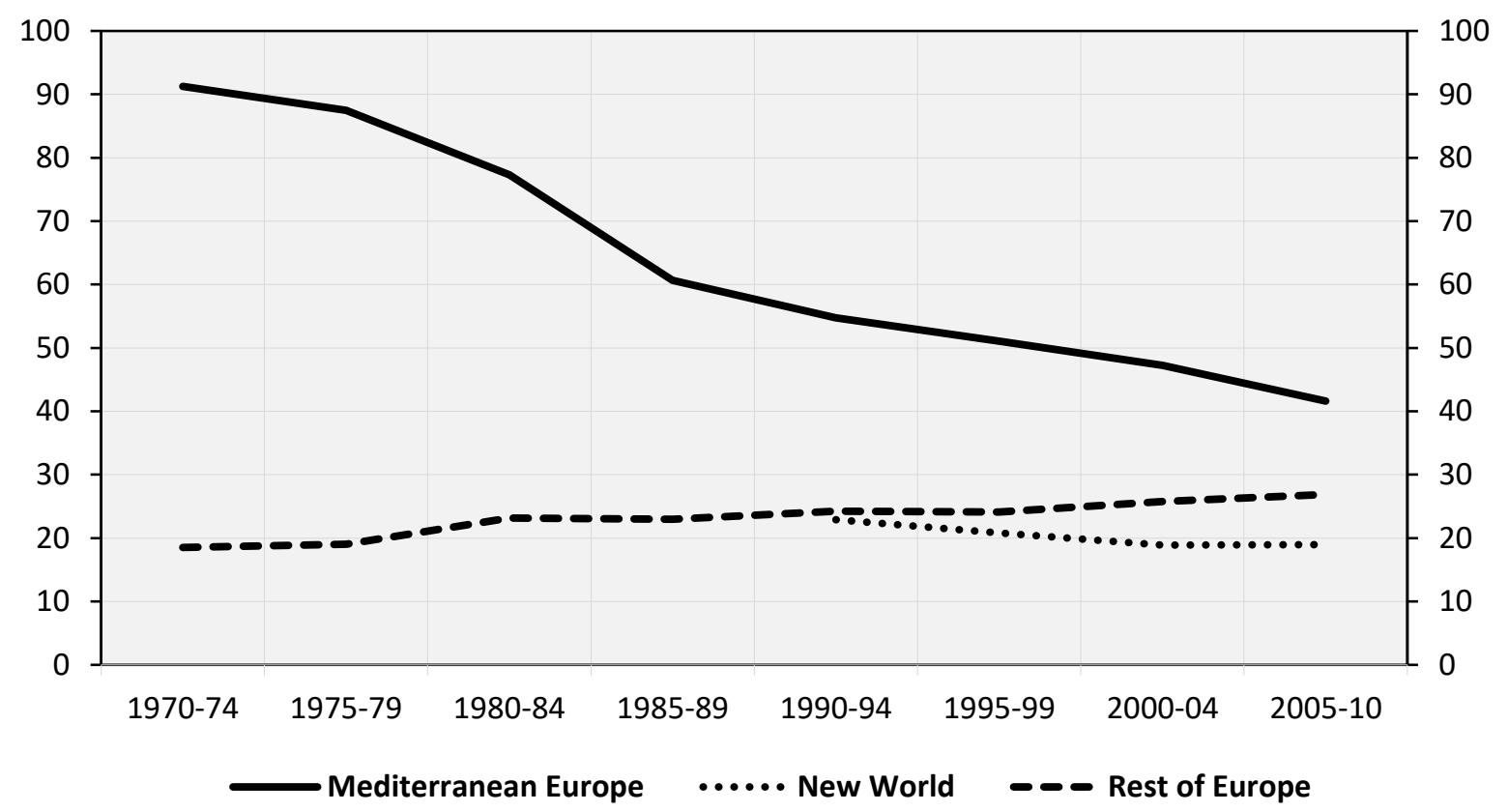

Notes: Mediterranean Europe: France, Italy, Spain and Portugal; Rest of Europe: Germany, Sweden, Austria, Belgium, Denmark, Switzerland, United Kingdom, The Netherlands; New World: Australia, United States, Chile and Argentina.

Source: Organization for Economic Co-operation and Development (1970-1984); International Organisation of Vine and Wine, in <http://www.oiv.int/oiv/ info/esstatistiquessecteurvitivinicole> [Accessed June 15, 2018].

\footnotetext{
${ }^{1}$ International Organisation of Vine and Wine, in <http://www.oiv.int/oiv/ info/esstatistiquessecteurvitivinicole>. [Accessed 15 June 2018].

${ }^{2}$ International Organisation of Vine and Wine, in 〈http://www.oiv.int/oiv/ info/esstatistiquessecteurvitivinicole >. [Accessed 15 June 2018].
} 
At the same time, this fact has brought about a global decline in wine demands, as the new consumers from the Northern Europe and the "New World" cannot score an equalizer (Anderson 2004; Banks and Overton 2010).

We can observe that the Mediterranean Europe - which is the main consumption area $^{3}$ (Pinilla and Serrano 2008; Unwin 1991) - has undergone a decrease in the last years. At the same time, this fact has brought about a global decline in wine demands, as the new consumers from the Northern Europe and the "New World" cannot score an equalizer (Anderson 2004; Banks and Overton 2010).

Some authors warn about the scarce predictive power of the simplified models of demand, which rely on the cost and rent in the case of wine. This is due to the fact that this product tends to differentiation, market regulations, moral, legal or social obstacles and irreversible demand curves (Morilla 2001). Therefore, we have to find explanations for these changes, other than rent or costs. Reasons should be looked for in social and cultural factors (Bardají 1992; Barber et al. 2008; Golan and Shalit 1993; Labys 1976; Lecocq and Visser 2006; Mosher and Johnsson 2005; Oczkowski 1994; Tapli and Ryan 1969; Troncoso and Aguirre 2006; St James and Christodoulidou 2011).

Among the possible causes for this evolution, we have to highlight, in the first place, the increase of rent and living standards in these countries, something which is necessarily linked to their industrialization and infrastructures towards modernity. This is not related to higher purchasing power, but -as previously mentioned - to people who are concerned about healthy

\footnotetext{
${ }^{3}$ International Organisation of Vine and Wine, in <http://www.oiv.int/oiv/ info/esstatistiquessecteurvitivinicole>. [Accessed 15 June 2018].
} 
life and, consequently, are less prone to drinking alcohol. There are other factors such as age and the existence of new drinks which are better adapted to the population's demands.

These changes have affected lifestyle and consumption habits, as well as the likes and preferences of the contemporary wine consumer. Nowadays, the daily consumption of table wine has been replaced by sporadic drinking of "quality wine". This type of wine is less fermented, fresh, young and kindly presented ${ }^{4}$ (Morilla 2001).

Today, the profile of the average consumer in the Mediterranean Europe is represented by people under 50 with high cultural level, university formation and standard or high income. For these people buying wine is a meditated process and its consumption relies on a gastronomic ritual that is occasionally practiced (Martín 2006; Millán and Yagüe 1997). This profile contrasts with the traditional wine consumer who preferred plain and cheaper, more fermented wine, which was consumed on a daily basis (Bernabéu and Olmeda 2002).

\subsection{Spain: a paradigmatic case of new consumption trends}

Spain can be considered a good example of this situation. One of the reasons for the falling consumption has been attributed to a series of drinks that are replacing wine in the Southern Europe, namely beer, soft drinks, sparkling drinks, FABs (Flavoured Alcoholic Beverages), fruit juice, mineral water, etc. Spain is one of those countries where beer and other drinks have experienced an extraordinary increase, as they are better adapted to young and urban people than wine is (see Figure 2).

\footnotetext{
${ }^{4}$ We observe significant changes that show a tendency towards high-quality wines. In $1987,85.2 \%$ wine that was drunk in Spain was table wine and only $14.8 \%$ had a designation of origin. By contrast, in 2010 the consumption of table wine decreased to $51 \%$, whereas high-quality wine has increased up to $49 \%$. The decreasing tendency in wine consumption is mainly due to this decrease in the consumption of table wine. Spanish Ministry of Agriculture, Fishing and Foodt, in < https://www.mapa.gob.es/es/alimentacion/temas/consumo-ycomercializacion-y-distribucion-alimentaria/panel-de-consumo-alimentario>. [Accessed 15 June 2013].
} 
Figure 2. Drinks consumption in Spain (litres per capita), 1970-2010

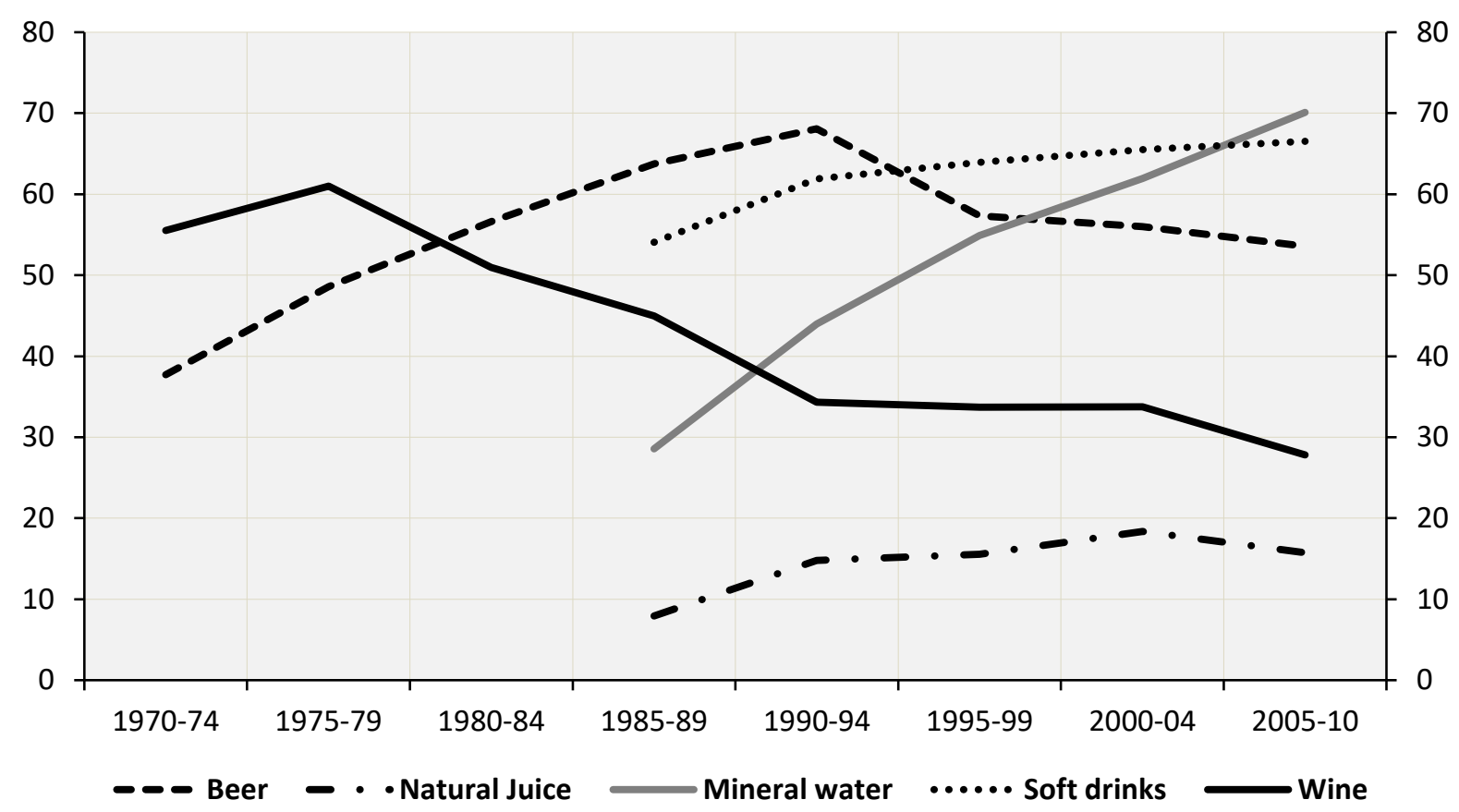

Source: Spanish Ministry of Agriculture, Fishing and Food, in https://www.mapa.gob.es/es/alimentacion/temas/consumo-y-comercializacion-y-distribucion-alimentaria/panelde-consumo-alimentario/ [Accessed June 15, 2018].

These changing habits are partly due to the modernization process, but there are other factors that may also lead to this situation. For instance, the high temperatures in the south of Spain may favour the consumption of cold drinks such as beer or soft drinks (Resa 2002), which are supported by important advertising campaigns. On the contrary, the wine sector shows a more humble commercial influence, and we should not forget legal restrictions for the consumption of alcohol (Millán and Yagüe 1997) which leads the consumer to confine wine consumption, especially drivers.

Indeed, Spanish and Southern European people nowadays drink less wine than their parents, and much less than their grandparents. Marketing studies carried out by the Spanish Wine 
Association (Federación Española del Vino-FEV) ${ }^{5}$ shows that hardly eight percent of respondents under 24 drink wine. It seems that Spanish youngsters see this drink as old and unattractive. They also think that you have to be an expert in order to enjoy wine, so that wine consumption is restricted to expertise (Martín 2006). We can also mention the important changes in the eating habits. Wine is part of Mediterranean life style, as it is stated by the Vine and Vine Law established in 2003 (Martín and Vidal 2004), and as it is admitted by experts (Moreno 2000), but, unfortunately, the Mediterranean diet is being replaced by fast food (Rodríguez Artalejo et al. 1996).

Therefore, at the beginning of the 20th century new models of wine consumption start to appear within a framework of new eating habits that have being built during these forty years (Mili 2005). The changes that have been described above about consumption do not constitute an isolated case. They are part of the global change in food and beverage consumption.

\subsection{Company structure in the Spanish wine sector}

The wine sector has been traditionally dual and highly fragmented. Small wineries, cooperatives and big companies are part of the same market (Yagüe and Jiménez 2002; Huetz de Lemps 1967), although they are very different. The Spanish sector is dominated by small wineries and cooperatives which operate at the local and regional level. They lack adequate marketing strategies, sales network and registered brands. That is why they depend on the distribution sector, which is strongly concentrated and it tends to the vertical integration and brand creation. This is something negative for wineries because of a bigger competence and the excess of supply and decreasing consumption (Gamble and Taddei 2007; Yagüe and Jiménez 2002).

\footnotetext{
${ }^{5}$ http://www.fev.es
} 
By contrast, the new markets, especially the United States and Australia, have big wineries. These companies produce massively, using different types of grape but with homogeneity in variety. This allows an important economic scale, and a high quality product at a good price (Bardají 1993; Cambolle and Giraud-Héraud 2003; Folwell and Volanti 2003; Gokcekus and Fargnoli 2007; Medina-Albaladejo, Martínez-Carrión and Ramon-Muñoz 2014). Prices are partly due to heavy investments in technology, advertising and marketing (Aylward 2003; Geraci 2004; Green, Rodríguez Zuñiga and Pierbattisti 2003; Jordan, Zidda and Lockshin 2007; Mora and Castaing 2006), taking into consideration the effect of the latter on wine consumption (Bardají 1992; Franke and Wilkox 1987; Woodside 1999). Thus, these new wineries are more market-oriented than the Spanish ones, which are too focused on their own product, especially cooperatives (Cambra 2006; López and Cambra 2005-2006).

Wine companies in the European countries are concentrated and oriented towards international markets. In addition, it seems that the situation of small wineries has improved due to the role of institutions. Several designations of origin started to develop their marketing activity individually in the last decades of the 20th century. They were collective solid brands with restricted access, letting companies develop their own strategies (Bardají 2003; Carbone 2003; Johnson and Bruwer 2007; McCutcheon, Bruwer and Li 2009; Remaud and Lockshin 2009; Schamel 2009; Yagüe and Jiménez 2002).

These politics of image were developed by the designations of origin. This origin, together with tradition, quality and other positive aspects, were the basis for these campaigns. Consequently, many small wineries have developed national promotion and marketing strategies, something that would have been difficult to carry out individually. 
It is also remarkable that at the end of the 90 s collective marketing strategies such as "Vinos de España" were developed by the Spanish Institute of External Trade (Instituto Español de Comercio Exterior-ICEX). The main aim of these strategies was to transmit the European consumer the distinguishing attributes of the Spanish wines, with a great variety and quality. These strategies pursued to avoid the consumer's confusion produced by the different designations of origin which appear separately (Espejel and Fandos 2009).

\subsection{Changes in the marketing strategies}

The first Spanish companies that adopted these marketing strategies were located in Jerez. They have used advertising from the end of the 19th century pursuing increasing sales. They resorted to several artistic resources such as painting, graphs or photography in order to elaborate labels or posters; literature was the basis for the messages; music was used for radio or tv advertising; architecture showed the rest of the world Jerez wineries and their elaboration process; even cinema was used. A great variety of elements - some of which have marked the contemporary culture of the country - have become part of the Spanish cultural patrimony from 1994. The Osborne bull is one of them (Rouzet and Seguin 2004; Nuñez 1997).

The case of the Jerez wineries was the exception. The reason why they were so precocious is the type of product at offer. Jerez wine was oriented both to the Spanish and the international market - particularly the British, where this product was bottled and labelled under different brands.

In general terms, the rest of the Spanish wineries did not adopt these strategies because they did not need it. The big cooperatives produced great amounts of homogeneous and low-quality wine. Despite of that, this type of wine was in the line of the likes of that moment and it was easily sold. This situation was given during the $50 \mathrm{~s}$, the $60 \mathrm{~s}$ and the first half of the $70 \mathrm{~s}$, as the 
Spanish wineries were clearly oriented to the product, not the market (Cambra 2006; López and Cambra 2005-2006; Fernández 2012; Martínez-Carrión and Medina-Albaladejo 2013).

The situation started to change at the end of the 70s and the Spanish wineries had to adapt to the new trends. They renewed their organization, distribution and trade structures. The wine companies got immersed in the process described above. They had to adapt themselves to the new marketing strategies and the new marketing line.

Professionalization will not be the only measure to increase sales. Another challenge in the 80 s was the opening of new markets. Exports helped increase sales and contributed to obtain bigger benefits as international consumers demanded high quality products, and Spanish companies started their opening process to international markets. This fact was accompanied by an improved wine elaboration and bottling process.

What is more, brand policies and diversification strategies were adopted, a different modus operandi from the 70s where wine was massively produced without paying attention to quality. It is from the 70 s onwards when wine started to be classified according to quality levels - age, designation of origin, flavour, etc. - which contributed to improve competitiveness and increased sales and benefits. All these new brands were characterized by images and designation of origin, as well as type, age, etc., which helped identify the quality of the product (Ríos 2003).

As for the introduction of specific marketing and advertising strategies, companies started to participate in wine testing festivals and advertising campaigns in the media. They also started to travel around in order to promote the product directly. In the 90 s other strategies were adopted, namely direct marketing, tasting, wine tours, etc. (Rouzet and Seguin 2004). The written media is the most used among all these resources, Rioja wines being the ones that have 
invested more money on these strategies (Albisu, Domínguez and Alejandre 1989; Albisu and Martín 1990; Martín and Albisu 1992).

We should not forget the role of the already mentioned designations of origin, which have accompanied the brand. Demand increased by means of the image of a product that is well defined (Albisu, Domínguez and Alejandre 1989; Albisu and Martín 1990; Martín and Albisu 1992).

Despite these marketing classic plans, there is recently a deficit in the acquisition of new strategies ${ }^{6}$. The strategies adopted by the Spanish wineries are not as developed as those in the United States $^{7}$ or Australia ${ }^{8}$ (Mahlau and Mili 2003; Nowak and Newton 2008; Thach 2009). There is no doubt that relational or direct marketing through new technologies will be the second big step that Spanish wineries will have to take in order to maintain their position in the domestic and international markets (Lynch and Ariely 2000; Rivera 2003).

3. Sources and methodology

\subsection{Sources}

Adverts were taken from five Spanish wine and gastronomy magazines: Apicius, La Semana Vitivinícola, Mi Vino, Sobremesa and Vitivinicultura.

Adverts selected belong to a time span of approximately 30 years, from the $70 \mathrm{~s}-$ when the wine consumption starts to change - to the beginning of the $21^{\text {st }}$ century. All the consulted magazines are published monthly except for La Semana Vitivinícola which is a weekly publication. As for

\footnotetext{
${ }^{6}$ In 2000, only five percent Spanish wineries were announced on the Internet, that is only 200 out of the 3700 registered wineries in Spain. Other techniques such as the email are still unexplored, as most webpages are just informative (Gómez-Limón, San Martín and Peña 2000). In 2009 percentage had increased to 37.4\% (259 out of 692 ) in the case of La Rioja and Aragón. However, only 65 of those 259 (25.1\%) used the online trade (MarzoNavarro, Pedraja-Iglesias and Vinzón 2010).

${ }^{7}$ Mainly California, as there are other regions that are less well known and whose wineries have similar problems to the Spanish ones, for instance, Texas (Rasch and Gretzel 2008).

${ }^{8}$ In 2001 10\% Australian wineries had their own webpage, doubling the number of Spanish wineries that had one. Besides, most of them were mainly based on online trade (Sellito, Wenn and Burgess 2003).
} 
the monthly magazines, six to eight issues per year were consulted. In the case of the weekly magazine La Semana Vitivinícola three issues per month were selected. This selection system does not belong to a specific criterium. It was established in order to cover the entire period of study, and therefore avoiding time constraints in the process of source consulting.

Our corpus contained 640 adverts out of which 560 corresponded to companies, whereas 80 belonged to designation of origin. Adverts were classified according to the magazine, year of publication, brand, name and type of the marketing company, as well as place, province and designation of origin. Additional information such as the existence of pictures or no text in the advert was also taken into consideration. Table 1 shows the number of adverts organized in terms of publication year and magazine where they appear.

Table 1. Number of adverts per magazine and publication year

\begin{tabular}{lll}
\hline Publication & Decades & Registers \\
\hline Apicius & $2000 \mathrm{~s}$ & 6 \\
La Semana Vitivinícola & $70 \mathrm{~s}, 80 \mathrm{~s}, 90 \mathrm{~s}, 2000 \mathrm{~s}$ & 254 \\
Mi Vino & $2000 \mathrm{~s}$ & 142 \\
Sobremesa & $80 \mathrm{~s}, 90 \mathrm{~s}, 2000 \mathrm{~s}$ & 194 \\
Vitivinicultura & $90 \mathrm{~s}$ & 44 \\
\hline
\end{tabular}

Source: own elaboration.

\subsection{Methodology: Word Frequency in textual analysis}

Word frequency can help us understand the importance of a word in discourse. When a word frequently occurs in certain context, it is highlighted and becomes what is known as keyword. Leech et al. (2001) call "keyword" as a salient lexical item in text, that is, an item occurring with high frequency in certain discourse contexts. Already in the $80 \mathrm{~s}$, Williams tried to define the concept of keyword as contention to certain ideas or values in a specific era or social time. 
In fact, some words get to acquire especial relevance in certain discourse, reflecting possible social, economic or political changes (Williams 1983; Kipnis 2006).

The first studies about frequency are found in the 19th century. Nevertheless, it is at the beginning of the 20th century when frequency gains importance within the linguistic scope. The General Service List (West 1953) the LOB (Francis and Kucera 1982) have contributed to this relevant position. These two corpora were a referent in frequency studies as they were built on the most frequent words in the English language taken from different written sources. We can also find corpora based on the oral language (Deulofeu and Blanche-Benveniste 2006), as well as others combining written and oral sources such as the British National Corpus. Yet, all these corpora rely on the so called general frequency, that is to say, the number of times a word occurs in general discourse. Traditionally, general word frequency has been the basis for Lexicography, specifically dictionary compilation (Kilgarriff 1997; McDonnald and Shillock 2001; Rychly 2008). In fact, nowadays dictionaries are usually built upon a descriptive basis. That is to say, dictionaries define words in terms of use, so that the meaning or meanings of a word are organized and considered in terms of people's use.

General frequency is to be distinguished from the specific frequency, that is to say, the number of times a word occurs in a given text, and it is the latter that is important for our analysis. Specific frequency has been used as an instrument of analysis in different disciplines and fields of study. In second language teaching and learning. Scholars such as Meara (2005), Waring and Takaki (2003) or Pigada and Schmidt (2006) have investigated how many times a word is necessary to be encountered by a learner so that it is acquired. Within this field of study, there is also an interest in vocabulary found in L2 textbooks and their frequency of occurrence (Alcaraz-Mármol 2011; Scholfield 1991). Other disciplines have recently taken advantage from 
word frequency in their studies. One of them is Critical Discourse Analysis, which has a qualitative tradition, but it has found in corpus linguistics and particularly word frequency a new tool for analysis. Word frequency has been applied by CDA in studies about mass media, especially the written press (Taylor 2014; Wodak and Meyer 2009; Orpin 2005). Despite their multiple applications, word frequency is not so commonly used in the field of marketing and advertising.

In our study word frequency is used for the linguistic analysis of wine advertising. Advertising has traditionally been linked to the fields of socioeconomy (Sutter 2002; Zeng et al., 2009) and even psychology (Fennis and Stroebe 2015; Verweijmeren et al. 2011). However, in the case of Applied Linguistics and especially regarding word frequency, there is a gap in how language can show certain patterns in the way certain products such as wine are meant to appeal potential consumers.

The linguistic software RANGE (Nation 2001) has been used for our analysis. RANGE allows us to quantify the number of words in a text as well as the occurrences of each word in a text (specific frequency) and in general discourse (general frequency).

We focused our analysis on content words, namely nouns, verbs, adjectives and adverbs, leaving aside prepositions or determiners whose lexical content is less informative than the first ones. Nevertheless, the personal pronouns "tú" (informal way of "you") and "usted" (a formal and polite way to say "you") were taken into account as they indicate the way the potential consumer is addressed by the advertiser - something that we considered relevant for our analysis.

The analysis was carried out considering all adverts together, and per decades, so that five different archives were obtained: four corresponded to each analysed decades and number five 
corresponded to a general one. The software offers three types of data: tokens - the number of words in the text-, types or the number of different words in the text, and finally, word families, including both inflected and derived forms. Words occurring under ten times were not analysed. Some adverts consisted just of a picture representing the product or something that evoked that product. This type of adverts was labelled "no message" (NM) and were also included in the corpus so that we could quantify the number of adverts that did not have linguistic support.

The quantitative analysis was completed with a qualitative analysis by classifying the content words into word families. The list of word families was designed ad hoc and it was based on the vocabulary found in the adverts. Up to fifteen categories were identified, among which some traditional and expected ones are found such as "family" or "quality", but also others which are more innovative and unexpected such as "the supernatural" or "art". Table 2 shows the list of word families.

Table 2. Word families

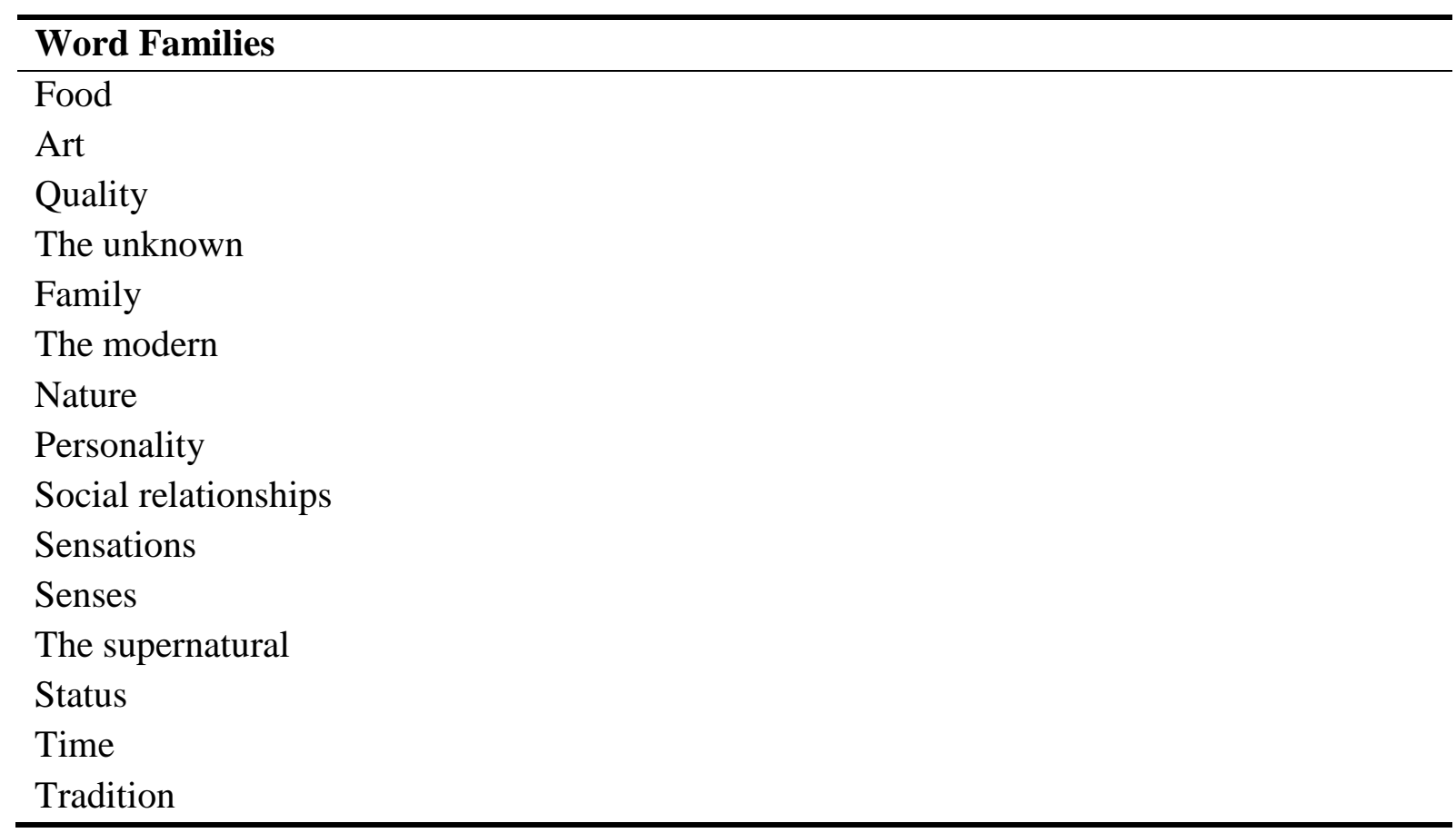

Source: own elaboration. 
The category "food" encompasses words denoting not only food as such but also things related to food such as cutlery and kitchenware; as for the category of "art", we have identified different manifestations and artists, among others; the category of "quality" is based on words denoting different quality degrees; "the unknown" category refers to what it is to be found out, and it normally requires audacity. It is important to highlight that "the unknown" is to be distinguished from "the supernatural", as the latter contains words related to religion, especially to the mystical. In this respect, a country may be unknown to someone, but is not be necessarily mysterious. That is why "the unknown" and "the supernatural" constitute two different categories.

The category "family" is mainly based on family members, although it also includes particular actions that are linked to the family environment. The rest of relationships are included in the category "social relationships". The categories "the modern" and "tradition" encompass everything related to innovation and customs, respectively. These categories should be distinguished from "time" which focuses on the quantity and organization of the latter. Within the category of "nature" we find natural landscapes. As for "personality", it is curious to find several adjectives that are not normally attributed to the inanimate. It is also necessary to distinguish between the categories of "senses" and "feelings", as the former are related to the physical whereas the latter evokes emotions.

Therefore, an analysis of linguistic data can help us reach conclusions about the development of marketing strategies within the wine world from the 70s to present day. 


\section{Results and discussion}

\subsection{General results}

As previously mentioned our corpus consists of 640 wine adverts that appeared in several Spanish wine magazines. The number of adverts is not strictly related to a linguistic analysis, but we consider it can nicely complement it. Thus, we can observe the following: in the first place, capitalist wineries have used more advertising techniques than cooperatives despite the great production of the latter.

As Table 3 shows, adverts corresponding to capitalist wineries have grown from $67.7 \%$ in the 70 s to $91.9 \%$ in the last decade, while advertising in cooperatives has fallen from $32.2 \%$ down to $8.1 \%$. These figures show that cooperatives have not adapted to the new market situation and the new trends of consumption ${ }^{9}$.

Table 3. Adverts according to the type of company and brand (\%)

\begin{tabular}{llllll}
\hline Decade & \multicolumn{2}{c}{ Company } & \multicolumn{3}{c}{ Presence of brand } \\
\hline & $\begin{array}{l}\text { Capitalist } \\
\text { company }\end{array}$ & Coop. & $\begin{array}{l}\text { Capitalist } \\
\text { company }\end{array}$ & Coop. & Total \\
\hline $70 \mathrm{~s}$ & 67.7 & 32.3 & 20.0 & 12.9 & 17.7 \\
$80 \mathrm{~s}$ & 77.7 & 22.3 & 50.8 & 25.0 & 44.4 \\
$90 \mathrm{~s}$ & 80.6 & 19.4 & 84.0 & 66.6 & 80.6 \\
$00 \mathrm{~s}$ & 91.9 & 8.1 & 87.1 & 80.7 & 86.6 \\
Total & 84.4 & 15.6 & 72.7 & 42.5 & 68.0 \\
\hline
\end{tabular}

Source: own elaboration.

\footnotetext{
${ }^{9}$ In 2008 cooperatives produced up to $70 \%$ of the total wine produced in Spain (COGECA 2010). Most of these cooperatives were created during Franco's dictatorship and they massively produced homogeneous low- quality wine. From the 80 s onwards they found it traumatic to adapt to the new trends (Martínez-Carrión and MedinaAlbaladejo 2010; Medina-Albaladejo 2015).
} 
If we pay attention to the percentage of messages that include a brand, we can observe that both types of company have improved. However, capitalist wineries have more adverts of this kind. In fact, $20 \%$ adverts of capitalist companies had already a brand in the 70 s, whereas this percentage has increased dramatically in the last decade up to $87.1 \%$. We can also observe an increase in the use of this technique on the part of cooperatives (from 12.9\% to 80.7\%), although in a minor scale.

Another aspect to be highlighted in the Spanish wine sector is the late implementation of all measures and techniques. Indeed, in the 80 s only $44.4 \%$ adverts included a brand.

Regarding designation of origin, Rioja is the most advanced in the use of advertising techniques with $25 \%$ of the adverts analysed in the last decade, although it was already the most advanced in the 70s (see Table 4).

Table 4. Adverts according to designation of origin (\%)

\begin{tabular}{lllll}
\hline Designation of origin & $\mathbf{7 0 s}$ & $\mathbf{8 0 s}$ & $\mathbf{9 0 s}$ & $\mathbf{0 0 s}$ \\
& & & & \\
\hline Rioja & 7.2 & 17.2 & 8.0 & 24.6 \\
Navarra & 9.3 & 1.2 & 11.2 & 5.9 \\
Valencia & 5.2 & 8.6 & 3.2 & 3.4 \\
La Mancha & 4.1 & 2.4 & 8.0 & 4.3 \\
Jerez-Manzanilla $^{\text {Ribera del Duero }}{ }^{1}$ & 3.1 & 4.9 & 0.0 & 2.8 \\
Rueda $^{2}$ & - & 1.2 & 1.6 & 13.0 \\
Valdepeñas $^{\text {Cava }}$ & - & 2.4 & 3.2 & 2.8 \\
Utiel-Requena $^{3}$ & 1.0 & 4.9 & 3.2 & 3.1 \\
Taroconte-Acentejo $^{4}$ & - & 1.2 & 9.6 & 5.6 \\
Rias Baixas $^{5}$ & - & 6.1 & 4.8 & 1.2 \\
Montilla $^{2}$ & - & - & 4.8 & 3.7 \\
\hline
\end{tabular}

Notes: 1: Created in 1982; 2: Created in 1980; 3: Created in 1986; 4: Created in 1992; 5: Created in 1988. Source: own elaboration. 
Navarra, Valencia and La Mancha are very traditional wine areas with very active companies and cooperatives, as well as a big territorial extension especially in the case of La Mancha (PanMontojo 1994, Medina-Albaladejo and Menzani 2016). Jerez differs from the ones above. Its adverts targeting the Spanish market were surprisingly few, although it was the first to use marketing techniques. The main reason is that Jerez wine has been traditionally oriented to international markets such as Great Britain (Sherry) (Montañés 2000; Fernández 2010).

As for the rest, we can observe different situations. For instance, the remarkable presence of the designation of origin Montilla-Moriles in the 70s and 80 s or other which are more recent and appear in the 90s such as Rías Baixas, Taroconte-Acentejo, Cava (internationally known with Freixenet and Codorniu), Rueda and especially Ribera del Duero. The latter is the Spanish designation of origin that has experienced the greatest growth in all aspects, with up to $13 \%$ adverts in the wine advertising campaign of the last decade, and it is to be placed in the second place after Rioja.

Valdepeñas or Utiel-Requena should also be remarked. They are traditional Spanish designations of origin which have known how to incorporate marketing policies since 1980. By contrast, the designation of origin Penedés has had a surprising scarce occurrence in our corpus - although it is fair to say that many Penedés wineries can be included in the Cava designation of origin. The designation of origin of Jumilla presents very few adverts and they are not very sophisticated.

It is also worth mentioning generic advertising based on collective brands. In the case of the Spanish wine, we refer to designation of origin when exclusively focused on a specific region. In the first place advertising techniques started to be used very late in the 80 s, and with very simple messages. 
Their evolution is similar to that in the corporate sector with more complex messages, and the use of images and icons which have evolved throughout the years. These techniques have been mostly used by several designation of origin such as La Mancha (8), Navarra (8), Jerez (7), Valencia (6), Rioja (5), Rueda (4), Montilla-Moriles (4) and Utiel-Requena (4). That is to say, those regions where wine corporations are more active in the use of advertising techniques coincide with those with collective brands. Therefore wine companies have adapted to the new situation with wineries that indicate their designation of origin and advertise these wineries are advertised through a collective brand.

\subsection{Most frequent word families: The $70 \mathrm{~s}$ and the $80 \mathrm{~s}$}

The 70s mark the beginning of the use of marketing techniques for the Spanish wineries, but with very simple adverts. Many wineries used no picture adverts where only the company name appeared. This is the expected modus operandi of a type of company that is mainly oriented to the product, not to marketing (Cambra 2006). In fact, our results show that most word families are related to the product itself, its elaboration process and trading. This is observed in the most used word families in this period, which include "vino" (wine), "exportación" (export) and “elaboración” (elaboration).

It was during these two decades when the Spanish wine sector started to adapt to the new market situation where more and more bottled high-quality old wine was demanded (Mili 2005; Martínez-Carrión and Medina-Albaladejo 2010). That is why there is a predominance of the word families such as: "criar" (grow) and "embotellar" (to bottle). This shows that the Spanish sector is not very diversified, where traditional red wine is the one that outstands. It is interesting to pay attention to the frequent use of the word family "exportación" (export) during this period. 
Exports had been very limited in former decades but they would significantly increase in these years due to the international demand of new consumers from Northern-Europe countries.

Table 5. Word families used in wine adverts in the 70s and 80s ( $<10$ frequency)

\begin{tabular}{llr}
\hline Word family & Members & Frequency \\
\hline Vino [Wine] & Vino, vinos, vinícola & 134 \\
Exportar [Export] & Exportación, exportador, exportadores & 43 \\
Elaborar [Elaborate] & Elaboración, elaborado, elaborador, & 32 \\
& elaboradores, elaborados & 27 \\
Tinto [Red] & Tinto, tintos & 25 \\
Criar [Grow] & Criador, criadores, crianza & 14 \\
Embotellar [To bottle] & Embotellado, embotelladores, embotellados, & \\
& embotellar & \\
Empresa [Company] & Empresa & 14 \\
Fino [Fine] & Finos & 10 \\
\hline
\end{tabular}

Source: own elaboration.

\subsection{Most frequent word families: The $90 \mathrm{~s}$ and the $2000 \mathrm{~s}$}

The 90s were a landmark in the Spanish wine advertising with the use of new marketing techniques and consumption patterns (Martínez-Carrión and Medina-Albaladejo 2010). As opposed to the picture found in the 70s and the $80 \mathrm{~s}$ - where most words in adverts were related to wine and the elaboration process itself - in the last two decades adverts have shown a significant increase of words which are not directly related to wine. We find up to ten words which occurring over 10 times in our corpus. The reason for this might point to an intention to identify the product with concepts other than those related to the elaboration process, which is normally unattractive to the consumer. Table 6 shows the most used word families in this period. 
Table 6. Word families used in wine adverts in the 90 s and 2000s ( $<10$ frequency)

\begin{tabular}{llr}
\hline Word familiy & Members & Frequency \\
\hline Grande [Great] & Grande, gran, grandes, grandeza & 39 \\
Aroma [Aroma] & Aroma, aromas, aromático & 30 \\
Tierra [Land] & Tierra, tierras & 25 \\
Tradición [Tradition] & Tradición, tradicional, tradiciones, tradicionales & 22 \\
Vino [Wine] & Vino, vinos & 21 \\
Tiempo [Time] & Tiempo, tiempos & 20 \\
Arte [Art] & Arte, artesanos, artesanía, artista & 19 \\
Pasión [Passion] & Pasión, pasiones, apasionados & 18 \\
Vivir [To live] & Vida, viva, vive, vives, vivirlas, vívelo & 17 \\
Familia [Family] & Familia, familiares familiar & 16 \\
Mundo [World] & Mundo, mundos & 15 \\
Placer [Pleasure] & Placer, placeres & 14 \\
Sensación [Sensation] & Sensaciones, sensación, sentir & 13 \\
Naturaleza [Nature] & Naturaleza, natural, naturales & 13 \\
Disfrutar [Enjoy] & Disfruta, disfrutan, disfrutar, disfrutarlo, disfrute & 13 \\
Calidad [Quality] & Calidad & 13 \\
Descubrir [Discover] & Descubierto, descubra, descubrimiento, descubrir, & 12 \\
& descúbralo & 12 \\
Sabor [Taste] & Sabor, sabores & 11 \\
Historia [History] & Historia, histórica & 11 \\
Obra [Work] & Obra, obras & 10 \\
Momento [Moment] & Momento, momentos & 10 \\
Saber [To taste] & Saber, sabe, sabemos, sabes, sabias, sabido, sabiduría, \\
Soñar [To dream] & sabios & 10 \\
\hline Source: & Soñar, sueño, sueños, sueña &
\end{tabular}

The top word family in these years is "grande" (great). Wineries start to insist in the fact that their wine is high-quality, a product that is far from common, but something that the consumer buys in special occasions. This idea is reinforced by the use of two word families, "quality" and "flavour". Whereas in the 50s or 60s wine was appreciated by its graduation, new trends rely on soft and natural wine with new flavor (Morilla 2001; Martín 2006).

The second most frequent word family is "tierra" (place of origin, land). As previously stated, Spanish models of production are based on small or mid-size wineries. The high frequency of 
the word family "land" indicates that this strong link between hand-making versus industrial production. By contrast, the strategy used in the rest of Europe is different. The new producers elaborate a simple, modern, fun wine that is promoted by strong advertising campaigns which offer competitive products (Aylward 2003; Medina-Albaladejo, Martínez-Carrión and RamonMuñoz 2014).

Terms such as "tradición" (tradition) "tiempo" (time) and "historia" (history) are also highly frequent in adverts. Time has to pass slowly in order to get high quality products and elaboration has to take place in traditional areas, indicating that tradition is a mark of distinction in Spain. Other terms are closely related to the word family "art". They describe wine as a very ancient Mediterranean product, as a work of art that can only be produced in special areas under specific weather conditions and elaborated by means of ancient techniques. It reinforces the idea of wine as something exclusive, of high quality, a "work of art" that is unique and is only drunk in special moments.

Most part of the wine business in Europe belongs to families, especially in the case of Spain (Martínez-Carrión and Medina-Albaladejo 2010). In fact, big corporations also use this term to define themselves and to link their product to tradition and parental heritage. That is why the word family "familia" (family) is one of the widely used in wine adverts.

Finally, it is also important to mention words related to the word family "pasión" (passion), one of the 10 most frequent families in adverts in the 90 s and the beginning of the 21 st century. Traditionally, the production systems have not been very sophisticated as the tendency was to produce table wine. At present, the production system has changed in order to be adapted to the new trend. Production is rigorously controlled so that grape is adequately selected and bred 
(Martínez-Carrión and Medina-Albaladejo 2010). That is to say, the wine process requires passion and dedication to obtain a high quality product.

To conclude, we have observed that wine advertising has been adapting to the new consumption models, where the product is no longer considered the basis of our diet but something closer to enjoyment, which some authors identify with social position (Capanaga 2004).

\subsection{Other linguistic aspects of interest}

Adverts with no message, or just a picture follow a more or less constant pattern during the four analysed decades. The number of these adverts is slightly higher in the $90 \mathrm{~s}$ - which may be related to the predominating minimalist type of message of that decade. Although we can find some examples of this type of adverts in the 70s and the 80s, it was in the $90 \mathrm{~s}$ where the use of images starts to proliferate, which at the same time could have been one of the reasons for the word cutting off, giving priority to the image than to the word to communicate the message.

The last decade (2000-2010) brought about the definite use of modern marketing techniques, with the generalized adoption of powerful images, which would reduce the use of words once again.

Table 7. Summary of data, period and decades

\begin{tabular}{lclc}
\hline Decade & No message (\%) & Wink to audience & Lexical variation (\%) \\
\hline $70 \mathrm{~s}$ & $6(6.2)$ & *Tú 0 / **Utd. 0 & 31.4 \\
$80 \mathrm{~s}$ & $3(3.7)$ & Tú 0 / Utd. 3 & 41.4 \\
$90 \mathrm{~s}$ & $8(12.9)$ & Tú 1 / Utd. 5 & 52.4 \\
$2000 \mathrm{~s}$ & $22(6.8)$ & Tú 38 / Utd. 9 & 32.4 \\
Total & $39(7.0)$ & Tú 39 / Utd. 17 & 28.6 \\
\hline
\end{tabular}

* A formal and polite way to say "you"; ** informal way of "you".

Source: own elaboration. 
As for the direct appeal to the audience, during the 80 s and 90s, the potential buyers are called "usted" (a formal and polite way to say "you"). By contrast, the 2000s are a turning point where "usted" is replaced by "tú" (informal way of "you"). The wine consumers have been traditionally considered old people - that is why "usted" was traditionally used. However, nowadays the new potential consumers are younger (between 30 and 50). They drink wine occasionally but this wine is normally of high quality and more expensive and exclusive than the wine a regular consumer over 50 may drink every day.

The use of "tú" instead of "usted" is also a way of calling the attention of young people. As previously mentioned, people under 30 do not normally drink wine. They identify themselves with other types of drink. That is why the use of "tú" might be an attempt to address this sector which is the most reluctant to wine drinking.

As for lexical variation, Spanish wineries continuously make use of the same number of words. Terms have changed along the years, but lexical density seems to be constant. This is related to the advertiser's aims, which are clearly defined, so that lexical variation is expected to be reduced. The product has been described in the same line along the years - with specific words related to quality, tradition and designation of origin.

\section{Conclusion}

We have observed that the type of vocabulary used in Spanish wine adverts have evolved from words which are more concrete and directly related to wine in the 70s and 80 s, to more symbolic and abstract terms which don't primarily belong to the wine world from the 90s onwards. This change is notably observed in capitalist companies, but the process has been slower in cooperatives, where they do not seem to adapt to the new marketing strategies. 
The evolution of the Spanish wine advertising starts in the 70s. But it is in the 80s and especially in the 90s when this evolution is consolidated. Thus, simple picture-less adverts are replaced by elaborated and complex messages with the image as one of the main resources, exploring semantic fields other than those related to production.

Therefore, at present wine adverts aim to transmit a high quality, well elaborated product that the consumer will enjoy. Spanish wineries seem to distinguish themselves from the rest by transmitting the idea of Mediterranean cultural tradition.

All in all, this research has sought to observe the ability of Spanish wineries to adapt to market changes, together with strategies undertaken in recent decades in order to stand out in an increasingly competitive and globalized market such as that of wine. The linguistic analysis has helped in the case of Spain, but future research must overcome these geographical limitations and include other cases from traditional producer countries (France, Italy) to check if they present similar trends. Likewise, it would be interesting to establish a comparative analysis with the strategies undertaken by the wineries from the "New World".

\section{Acknowledgments}

This work was supported by the Spanish Ministry of Science, Innovation and Universities under Grant HAR2016-76814-C2-1-P and HAR2015-64076-P (AEI/FEDER, EU).

\section{References}

Albisu, Luis M., José A. Domínguez, and José L. Alejandre. 1989. Actitud del consumidor español ante la publicidad del vino. Madrid: Instituto Nacional de Investigaciones Agrarias.

Albisu, Luis M., and Dolores Martín. 1990. "La publicidad de vino en España.” In Publicidad en el sistema agroalimentario. Un análisis comparativo internacional, edited by Julián Briz, 101-122. Madrid, Ediciones Mundi-Prensa. 
Alcaraz-Mármol, Gema. 2011. "Vocabulary input in classroom materials: Two EFL coursebooks used in Spanish schools." Revista Española de Lingüística Aplicada 24:9-28.

Anderson, Kym. 2004. The World's Wine Markets. Globalization at work. Cheltenham: Edward Elgar. Aylward, David K. 2003. "A documentary of innovation support among New World wine industries." Journal of Wine Research 14 (1): 31-43.

Banks, Glenn, and John Overton. 2010. "Old World, New World, Third World? Reconceptualising the Worlds of Wine." Journal of Wine Research 21 (1): 57-75.

Barber, Nelson, Tim Dodd, and Richard Ghiselli. 2008. "Capturing the younger wine consumer." Journal of Wine Research 19 (2): 123-141.

Bardají, Isabel. 1992. "El consumo de vino.” Revista de Estudios Agro-Sociales y Pesqueros 162:153182.

Bardají, Isabel. 1993. "El vino en Estados Unidos.” Revista de Estudios Agro-Sociales y Pesqueros $163: 219-257$.

Bardají, Isabel. 2003. "Quality wines in Spain." In Wine in the Old World. New risks and opportunities, edited by Silvia Gatti., Eric Giraud-Héraud, and Samir Mili, 73-84. Milano: Franco Angeli.

Bernabéu, Rodolfo, and Miguel Olmeda. 2002. "Factores que condicionan la frecuencia de consumo de vino." Distribución y consumo 57:57-61.

Cambolle, Claire, and Eric Giraud-Héraud. 2003. "Economic analysis of certification by an AOC." In Wine in the Old World. New risks and opportunities, edited by Silvia Gatti., Eric Giraud-Héraud, and Samir Mili, 15-28. Milano: Franco Angeli.

Cambra, Jesús J. 2006. "El mundo del vino bajo el prisma del Márketing." E-Deusto 49:30-34.

Capanaga, Pilar. 2004. "Publicidad y nuevos consumos: algunos motivos para hablar del lenguaje del vino en la clase de E/LE.” AISPI Actas XXII: 27-45.

Carbone, Anna. 2003. "The role of Designation of Origin in the Italian food system." In Wine in the Old World. New risks and opportunities, edited by Silvia Gatti., Eric Giraud-Héraud, and Samir Mili, 29-40. Milano: Franco Angeli.

COGEGA-General Committee for Agricultural Cooperation in the European Union. 2010. Agricultural cooperatives in Europe. Main issues and trends. Brussels. Accessed 15 June 2018. http://www.agro-alimentarias.coop/ficheros/doc/03020.pdf

Deulofeu, Henri J., and Claire Blanche-Benveniste. 2006. "C-Oral-Rom French corpus." In Spoken Language Corpus and Linguistic Informatics, edited by Yuji Kawaguchi, Susumu Zaima, and Toshihiro Takagaki. Amsterdam: John Benjamins Publishing Company. 
Espejel, Joel, and Carmina Fandos. 2009. "Wine marketing strategies in Spain: A structural equation approach to consumer response to protected designations of origin (PDOs)" International Journal of Wine Business Research 21 (3): 267-288.

Fennis, Bob, and Wolfrang Stroebe. 2015. The psychology of advertising. Hove, East Sussex: Psychology Press.

Fernández, Eva. 2010. “Unsuccessful responses to quality uncertainty: Brands in Spain's sherry industry, 1920-1990. Business History 52:100-119.

Fernández, Eva. 2012. "Especialización en baja calidad. España y el mercado internacional del vino, 1950-1990." Historia Agraria 56:41-76.

Folwell, Raymond J., and Milko Volanti. 2003. "The changing market structure of the USA wine industry." Journal of Wine Research 14 (1): 25-30.

Francis, W. Nelson, and Henry Kucera. 1982. Frequency Analysis of English Usage. Houghton: Mifflin Company.

Franke, George., and Gary Wilcox. 1987. "Alcoholic beverage and consumption in the United States, 1964-1984." Journal of Advertising 16 (3): 22-30.

Gamble, Paul R., and Jean-Claude Taddei. 2007. "Restructuring the French wine industry: The case of the Loire." Journal of Wine Research 18 (3): 125-145.

Geraci, Victor W. 2004. "Fermenting a Twenty-First Century California Wine Industry." Agricultural History 78 (4): 438-465.

Gokcekus, Omer, and Andrew Fargnoli. 2007. "Is globalization good for wine drinkers in the United States?" Journal of Wine Economics 2 (2): 187-195.

Golan, Amos, and Haim Shalit. 1993. "Wine quality differentials in hedonic grape pricing." Journal of Agricultural Economics 44:311-321.

Gómez-Limón, José A., Roberto San Martín, and Nuria Peña. 2000. "El uso de Internet en el comercio y el marketing vinícola. Análisis del sector en España." Revista de Estudios Agro-Sociales y Pesqueros 189:119-156.

Green, Raúl, Manuel Rodríguez Zuñiga, and Leandro Pierbattisti. 2003. "Global market changes and Business behavior in the wine sector." In Wine in the Old World. New risks and opportunities, edited by Silvia Gatti., Eric Giraud-Héraud, and Samir Mili, 157-170. Milano: Franco Angeli.

Huetz de Lemps, Alain. 1967. Vignobles et vins du Nord-Ouest d'Espagne. Bordeaux: Féret \& Fils.

Johnson, Ray, and Johan Bruwer. 2007. "Regional brand image and perceived wine quality: the consumer perspective." International Journal of Wine Business Research 19 (4): 276-297

Jordan, Rohan, Pietro Zidda, and Larry Lockshin. 2007. "Behind the Australian wine industry's success: does environment matter?" International Journal of Wine Business Research 19 (1): 14-32. 
Kilgarriff, Adam. 1997. "Putting frequencies in the dictionary." International Journal of Lexicography 10:135-155.

Kipnis, Andrew. 2006. "Suzhi: A keyword approach.” The China Quarterly 1:295-313.

Labys, Walter A. 1976. "An international comparison of price and income elasticities for wine consumption." Australian Journal of Agricultural Economics 20:33-36.

Lecocq, Sébastien, and Michael Visser. 2006. "What determines wine prices: Objective vs. sensory characteristics." Journal of Wine Economics 1 (1): 42-56.

Leech, Geoffrey, Paul Rayson, and Andrew Wilson. 2001. Word Frequencies in Written and Spoken English. London: Longman.

López, María E., and Jesús Cambra. 2005-2006. "Algunas reflexiones sobre la importancia del marketing en el mundo del vino." Annales. Anuario del Centro de la Universidad Nacional de Educación a Distancia de Barbastro XVIII: 231-252.

Lynch, John G., and Dan Ariely. 2000. "Wine Online: Search Costs Affect Competition on Price, Quality and Distribution." Marketing Science 19 (1): 83-103.

Mahlau, Mario, and Samir Mili. 2003. "Marketing strategies for Spanish wines: a comparative appraisal." In Wine in the Old World. New risks and opportunities, edited by Silvia Gatti., Eric Giraud-Héraud, and Samir Mili, 41-52. Milano: Franco Angeli.

Martín, Dolores, and Luis M. Albisu. 1992. El mercado del vino de la Denominación de Origen Rioja. Madrid: Ministerio de Agricultura, Pesca y Alimentación.

Martín, Víctor J. 2006. "Consumo de vinos. Principales características y distribución comercial." Distribución y Consumo enero-febrero: 60-101.

Martín, Miguel A., and Fernando Vidal. 2004. "La nueva ley de la viña y del vino: líneas maestras y consecuencias para las actuales denominaciones de origen." Revista de Estudios Agro-Sociales y Pesqueros 204:47-66.

Martínez-Carrión, José M., and Francisco J. Medina-Albaladejo. 2010. "Change and Development in the Spanish Wine Sector, 1950-2009.” Journal of Wine Research 21 (1): 77-95.

Martínez-Carrión, José M., and Francisco J. Medina-Albaladejo. 2013. "La competitividad internacional de la industria vinícola española durante la globalización del vino." Revista de Historia Industrial 52 (2): $139-174$

Marzo-Navarro, Mercedes, Marta Pedraja-Iglesias, and Lucia Vinzón. 2010. “Orientación hacia el desarrollo del turismo del vino de las webs de las bodegas de la Rioja y Aragón (España). Journal of Technology, Management \& Innovation 5 (2): 113-132. 
McCutcheon, Emily, Johan Bruwer, and Elton LI. 2009. "Region of origin and its importance among choice factors in the wine-buying decision making of consumers." International Journal of Wine Business Research 21 (3): 212-234.

McDonnald, Scott, and Richard Shillock. 2001. "Rethinking the Word Frequency Effect: The Neglected Role of Distributional Information." Lexical Processing. Language and Speech 44 (3): 295-322.

Meara, Paul. 2005. "Lexical Frequency Profiles: A Monte Carlo Analysis.” Applied Linguistics 26:3247.

Medina-Albaladejo, Francisco J., José M. Martínez-Carrión, and Josep M. Ramon-Muñoz. 2014. "El mercado mundial de vino y la competitividad de los países del hemisferio sur, 1961-2010.” América Latina en la Historia Económica 21 (2): 40-83.

Medina-Albaladejo, Francisco J. 2015. "Co-operative wineries: Temporal solution or efficient firms? The Spanish case during late Francoism, 1970-1981.” Business History 57:589-613.

Medina-Albaladejo, Francisco J., and Tito Menzani. 2016. "Co-operative Wineries in Italy and Spain in the Second Half of the Twentieth Century: Success or Failure of the Co-operative Business Model." Enterprise and Society 18 (1): 32-71.

Mili, Samir. 2005. "Transformaciones del consumo alimentario y su repercusión en el sistema agroalimentario." Revista de Estudios Agro-Sociales y Pesqueros 205:221-247.

Millán, Ángel, and María J. Yagüe. 1997. "Consumo de vino. Evolución y tendencias." Distribución y Consumo 32:17-41.

Montañés, Enrique. 2000. “El vino de Jerez en el sector exterior español, 1838-1885.” Revista de Historia Industrial 17:189-209.

Mora, Pierre, and Yohan Castaing. 2006. Buenas prácticas en marketing del vino. 20 estudios de casos de vinos del mundo. Madrid: Mundi-Prensa.

Moreno, Alfonso. 2000. "Efectos saludables del consumo moderado de vino." Zubía 12:59-102.

Morilla, José. 2001. "Cambios en las preferencias de los consumidores de vino y respuestas de los productores en los dos últimos siglos." In Viñas, bodegas y mercados. El cambio técnico en la vitivinicultura española, 1850-1936, edited by Juan Carmona, Josep Colomé, Juan Pan-Montojo, and James Simpson, 13-38. Zaragoza: Prensas Universitarias de Zaragoza.

Mosher, James F., and Diane Johnsson. 2005. "Flavored Alcoholic Beverages: An International Marketing Campaign that Targets Youth.” Journal of Public Health Policy 26 (3): 326-342.

Nation, I.S.P. 2001. Learning vocabulary in another language. Cambridge: CUP.

Nowak, Linda I., and Sandra Newton. 2008. "Using winery web sites to launch relationships with Millenials." International Journal of Wine Business Research 20 (1): 53-67. 
Nuñez, Antonio. 1997. "Arte y publicidad, un matrimonio de conveniencia. Breves apuntes sobre el arte y la publicidad del Vino Fino y del Brandy de Jerez." In Actas de las II Jornadas del Vino Fino, edited by Alberto Ramos Santana, 69-108. Cádiz: Ayuntamiento de El Puerto de Santa María.

Organization for Economic Co-operation and Development (OCDE). 1970-1984. Food consumption statistics. Paris.

Oczkowski, Edward. 1994. "A hedonic price function for Australian premium table wine." Australian Journal of Agricultural Economics 38 (1): 93-110.

Orpin, Debbie. 2005. "Corpus Linguistics and Critical Discourse Analysis: Examining the ideology of sleaze.” International Journal of Corpus Linguistics 10:37-61.

Pan-Montojo, Juan. 1994. La bodega del mundo. La vid y el vino en España (1800-1936). Alianza: Madrid.

Pigada, Maria, and Norbert Schmidt. 2006. "Vocabulary acquisition from extensive reading: A case study." Reading in a Foreign Language 18:1-28.

Pinilla, Vicente, and Raúl Serrano. 2008. "The Agricultural and Food Trade in the First Globalization: Spanish Table Wine Exports 1871 to 1935 A Case Study.” Journal of Wine Economics 3 (2): 132148.

Rasch, Leslie, and Ulrike Gretzel. 2008. "Wineries' Involvement in Promoting Tourism Online: The Case of Texas." Pasos. Revista de Turismo y Patrimonio Cultural 2:317-326.

Remaud, Hervé, and Larry Lockshin. 2009. "Building brand salience for commodity-based wine regions." International Journal of Wine Business Research 21 (1): 79-92.

Resa, Sylvia. 2002. "Aguas envasadas, zumos, refrescos y cervezas: una demanda en crecimiento." Distribución y consumo 64:75-85.

Ríos, Sonia 2003. "ENATE: tradición vitivinícola, arte actual y diseño gráfico. Historia, arte e imagen de marca en etiquetas de vino." Boletín de Arte 24:363-392.

Rivera, Luis M. 2003. "El nuevo marketing vitivinícola." In El mercado del vino: reflexiones y propuestas de futuro, edited by Juan S. Castillo Valero, 103-116. Cuenca: Universidad de Castilla-La Mancha.

Rodríguez Artalejo, Fernando, José R. Banegas, Auxiliadora Graciani, Ramón Hernández de Vecino, and Juan del Rey Calero. 1996. "El consumo de alimentos y nutrientes en España en el periodo 1940-1988. Análisis de su consistencia con la dieta mediterránea." Medicina Clínica 106 (5): 161168.

Rouzet, Emmanuelle, and Gérard Seguin. 2004. El Marketing del vino. Saber vender el vino. Madrid: Mundi-Prensa. 
Rychly, Pavel. 2008. “A Lexicographer-Friendly Association Score.” Proceedings of Recent Advances in Slavonic Natural Language Processing RASLAN, 2008: 6-9.

Sellito, Carmine, Andrew Wenn, and Stephen Burgess. 2003. "A Review of the Web Sites of Small Australian Wineries: Motivations, Goals and Success." Information Technology and Management 4 (2-3): 215-232.

Schamel, Günter. 2009. "Dynamic analysis of brand and regional reputation: The case of wine." Journal of Wine Economics 4 (1): 62-80.

Scholfield, Phil. 1991. "Vocabulary rate in coursebooks - living with an unstable lexical economy." Paper presented at the fifth Symposium on the description and/or comparison of English and Greek, Aristotle University, Thessaloniki.

St James, Melissa, and Natasa Christodoulidou. 2011. "Factors influencing wine consumption in Southern California consumers." International Journal of Wine Business Research 23 (1): 36-48.

Sutter, Daniel. 2002. "Advertising and Political Bias in the Media: The Market for Criticism of the Market Economy." American Journal of Economics and Sociology 61:725-745.

Tapli, J., and W. Ryan. 1969. "The prospects for wine in Australia." Quarterly Review of Agricultural Economics 22:197-209.

Taylor, Charlotte. 2014. "Investigating the representation of migrants in the UK and Italian press: A cross-linguistic corpus-assisted discourse analysis." International Journal of Corpus Linguistics 19:368-400.

Thach, Liz. 2009. "Wine 2.0 - The next phase of wine marketing? Exploring US winery adoption of wine 2.0 components." Journal of Wine Research 20 (2): 143-157.

Troncoso, Javier L., and Medardo Aguirre. 2006. "Demanda y oferta de vino en el periodo 1980-2004: un análisis econométrico." Panorama socioeconómico 44:26-32.

Unwin, Tim. 1991. Wine and the vine: an historical geography of viticulture and the wine trade. London: Routledge.

Verweijmeren, Thijs, Johan Karremans, Wolfrang Stroebe, and Daniel Wigboldus. 2011. "The workings and limits of subliminal advertising: The role of habits." Journal of consumer psychology 21:206213.

Waring, Rob, and Misako Takaki. 2003. "At what rate do learners learn and retain new vocabulary from reading a graded reader?" Reading in a Foreign Language 15:130-163.

West, Michael. 1953. A General Service List of English Words. London: Longman, Green \& Co.

Williams, Raymon. 1983. Keywords. A vocabulary of culture and society. Oxford: OUP.

Wodak, Ruth, and Michael Meyer. 2009. Methods of Critical Discourse Analysis. London: Sage. 


\section{Journal of Evolutionary Studies in Business}

Woodside, Arch G. 1999. "Advertising and Consumption of Alcoholic Beverages." Journal of Consumer Psychology 8 (2): 167-186.

Yagüe, María J., and Ana I. Jiménez. 2002. "La denominación de origen en el desarrollo de estrategias de diferenciación: percepción y efectos de su utilización en las sociedades vinícolas de Mancha y Valdepeñas.” Revista de Estudios Agro-Sociales y Pesqueros 197:179-204.

Zeng, Fue, Li Huang, and Dou Wenyu. 2009. "Social Factors in User Perceptions and Responses to Advertising in Online Social Networking Communities." Interactive Advertising 10:1-13.

This is an Open Access article distributed under the terms of the Creative Commons Attribution-Non-Commercial-No Derivatives License (http://creativecommons.org/licenses/by-nc-nd/4.0/), which permits non-comercial re-use and distribution, provided the original work is properly cited, and is not altered or transformed in any way. 